\title{
Distribution and assessment of trace metal contamination in the surface sediments of the Meliane River and the Coast of the Gulf of Tunis (Tunisia, Mediterranean Sea)
}

Asma Yahyaoui, Rim Ben Amor, Myriam Abidi, Giovanni Grieco, Moncef Gueddari, and Lassaad Chouba

\section{QUERY SHEET}

This page lists questions we have about your paper. The numbers displayed at left are hyperlinked to the location of the query in your paper.

The title and author names are listed on this sheet as they will be published, both on your paper and on the Table of Contents. Please review and ensure the information is correct and advise us if any changes need to be made. In addition, please review your paper as a whole for typographical and essential corrections.

Your PDF proof has been enabled so that you can comment on the proof directly using Adobe Acrobat. For further information on marking corrections using Acrobat, please visit http://journalauthors.tandf.co.uk/production/acrobat.asp; https://authorservices.taylorandfrancis.com/how-to-correct-proofs-with-adobe/

The CrossRef database (www.crossref.org/) has been used to validate the references.

\section{AUTHOR QUERIES}

Q1 Please check that the hierarchy of ALL section heads and subheads in the manuscript are correct.

Q2 Please provide complete details for (Dawson et al., 1998, Chetty et al., 2019, M'âamri, 1998, Ben Ayed et al., 1983, Kabouchi et al., 2020, Saeedi et al., 2015 and Abdullah et al., 2019) in the reference list or delete the citation from the text.

Q3 There is no mention of (Abdallah \& Mohamed 2019, Ben Ayed et al. 1984, Caglar et al. 2019, Chetty \& Pillay 2019, Dawson \& Macklin 1998, Filgueiras et al. 2002) in the text. Please insert a citation in the text or delete the reference as appropriate.

Q4 Please provide the page range for Ref. Added et al. 2003.

Q5 Please provide details for Refs. Agence nationale de Protection de 1'Environnement (ANPE) 2014; Ben Charrada 1997; Jouirou 1982; Sliti 1990.

Q6 Please provide the page range for Ref. Ben Amor et al. 2019.

Q7 Please check if Ref. Ben Ayed et al. 1984 is OK as typeset.

Q8 Please provide the page range for Ref. Ben Lamine et al. 2012.

Q9 Please provide the volume number for Ref. Joy et al. 2019.

Q10 Please provide the volume number for Ref. Köse et al. 2019.

Q11 Please provide the publisher location and publisher name for Ref. Stumm and Morgan 1970.

Q12 Please list upto 10 author names for all "et al." type references.

Q13 Please provide missing citation(s) for Table 6. 
Please provide the significance of bold values in Table 7 . 


\title{
Distribution and assessment of trace metal contamination in the surface sediments of the Meliane River and the Coast of the Gulf of Tunis (Tunisia, Mediterranean Sea)
}

\author{
Asma Yahyaoui ${ }^{a, b}, \operatorname{Rim}$ Ben Amor ${ }^{\mathrm{b}}$, Myriam Abidi ${ }^{\mathrm{b}}$, Giovanni Griecoc, Moncef Gueddari ${ }^{\mathrm{b}}$, and \\ Lassaad Chouba ${ }^{a}$ \\ ${ }^{a}$ Laboratory of Marine Environment, National Institute of Marine Science and Technology (INSTM), Goulette, Tunisia; ${ }^{\mathrm{b}}$ Faculty of \\ Sciences of Tunis, University Tunis-El Manar, Tunis, Tunisia; 'Department of Earth Sciences "Ardito Desio", University of Milan, \\ Milan, Italy
}

ABSTRACT

The Meliane River, the second longest and most important river in Tunisia, is one of the major rivers that flow into the Gulf of Tunis. However, it is known by its significant discharges of urban and industrial activities that have seriously affected the quality of the aquatic ecosystem. The highest amounts of Cadmium (Cd), Copper ( $\mathrm{Cu})$, Lead (Pb), Zinc $(\mathrm{Zn})$, Nickel (Ni), Chromium ( $\mathrm{Cr})$ and Manganese $(\mathrm{Mn})$ in the surface sediments of the Meliane River indicate that the downstream part is the most polluted area. The chemical speciation shows that the majority of the trace metals are bound to a reducible fraction ( $\mathrm{Zn}, \mathrm{Mn}, \mathrm{Cr}$ and $\mathrm{Ni}$ ) and the $\mathrm{Pb}$ and $\mathrm{Cu}$ are bound to the oxidizable fraction. The $\mathrm{Cd}$ is linked to the exchangeable fraction, which indicates its high mobility and toxicity. Both the contamination and enrichment factors values of some trace metals are elevated in the downstream part of the Meliane River. The percentage of the risk assessment code in $\mathrm{Cd}$ is $59.8 \%$, which presents a very high environmental risk. Therefore, the spatial distribution of trace elements in the surface sediments is characterized by its high concentration of metals in the downstream part of the Meliane River. These concentrations decrease as a function of change in the physicochemical parameters from the freshwater-saltwater mixing zone to marine stations.

\section{KEYWORDS}

Trace metals; surface sediments; chemical speciation; river pollution; anthropogenic sources

\section{Q1 Introduction}

Trace metals are persistent, toxic and non-biodegradable elements. They constitute a serious pollutant for any aquatic system (Pekey 2006; Joy et al., 2019). The major sources of trace elements are natural due to the erosion of geological materials and anthropogenic caused by domestic, industrial and agricultural activities (Dawson et al., 1998; Demirak et al., 2006; Sakan et al., 2013; Leung et al., 2017; Çağlar et al., 2019; Köse et al., 2019). Besides, in recent years, the rapid urbanization and industrialization have affected the transport of the trace metals in the aquatic environment (Lusher and Ramsden, 2000; Tzimopoulos et al., 2005; Chetty et al., 2019). The contamination of river water and surface sediments by trace metal is becoming the main quality problem in rapidly-developing cities as maintenance of water and sediment quality as well as hygienic structure do not grow with population and urbanization (Ahmad et al., 2010; Bhuyan et al., 2019). Thus, the aquatic ecosystem can be affected by contamination with trace metals in the sediments and, therefore, bioassimilation and bioaccumulation of pollutants in the biota threaten both the human health and the ecosystem (Raghunath et al., 1999; Li et al., 2004; Ip et al., 2007; Dou et al., 2013). In fact, the huge amount of trace metals released into rivers may be greatly accrued in water, sediment and biota (McGeer et al., 2000; Jones et al., 2001; Almeida et al., 2002; Xu et al., 2004; Yi et al., 2011). The coastal environments are also exposed to this type of pollution. Tunisia coastline represents about $2.5 \%$ of the total of Mediterranean coastline (Ennouri et al., 2010). The Gulf of Tunis coastline opens to the central Mediterranean and plays an utmost important economic role to the country. It is densely populated (2.5 million people) and 
characterized by the presence of massive economic and industrial activities (Ennouri et al., 2010). Moreover, due to intensive anthropogenic activities, the Meliane River has become a major source of pollution with trace metals in the Gulf of Tunis coast, which forced the state to prohibit swimming in the coastline between Rades and Hammam-lif. This area, centered by the Meliane River discharging significant amounts of sediment, has a major importance in the capital of Tunis. It has been affected by the problem of urbanization and continuous development of industrial and agricultural sectors. Thus, huge amounts of pollutants released from different types of water discharges makes Meliane River subject to significant pollution risks and threatens the quality of water and sediment flowing from its upstream to its downstream, and transported to the sea. Due to the natural processes and the anthropogenic interventions, the coastline sediment balance is very sensitive to any environmental change (Zaaboub et al., 2014a; Brahim et al., 2015). Several previous studies (Zaaboub et al., 2014b; Ben Amor et al., 2019) have investigated the trace metals in the surface sediments of the Gulf of Tunis without focusing on the potential sources of these elements. In this work, in addition to the assessment of trace metals in marine sediments, we are interested to their inputs by Meliane River from the watershed to the sea. This study can help establish background values for the contaminants studied that can be useful in establishing new pollution events and potentially help identify point sources of contamination. In fact, geochemistry knowledge about the trace metals transported from the river to the sea is limited due to the fact that geochemical characteristics and the spatial distribution on the riverine were infrequently reported (Liu et al., 2019). Indeed, the concentrations of trace metals in the surface sediments of the Meliane River were rarely studied.

The main objectives of this study were (1) to quantify and evaluate the spatial distribution of trace metals in surface sediments of Meliane River and marine stations; (2) to assess the degree of contamination and toxicity of trace metals in each fraction of surface sediments and (3) to estimate the degree of the menaces of the trace metals using the pollution indicators and risk assessments.

The amount of Cadmium $(\mathrm{Cd})$, Copper $(\mathrm{Cu})$, Lead $(\mathrm{Pb})$, Zinc $(\mathrm{Zn})$, Nickel $(\mathrm{Ni})$, Chromium $(\mathrm{Cr})$ and Manganese $(\mathrm{Mn})$ were determined by the total amount of trace metals and sequential chemical extraction. The statistical analysis and the measurement of different contamination indexes were carried out.

\section{Study area}

The Meliane River is located in northern Tunisia between $36^{\circ}$ and $36^{\circ} 45^{\prime}$ north latitude and $9^{\circ} 30^{\prime}$ and $10^{\circ} 15^{\prime}$ east longitude (Figure 1). It covers a distance of $150 \mathrm{~km}$. The study area begins from the downstream of the Bir M'Cherga Dam, located near the Zaghouan region, $47 \mathrm{~km}$ from southwest of Tunis, to $35 \mathrm{~km}$ from its exit in the Gulf of Tunis (Ayadi and Bargaoui, 1998). At the Bir M'Cherga Dam, it drains a catchment of $1442 \mathrm{~km}^{2}$ and extends for $100 \mathrm{~km}$ in length, and between 8 and $35 \mathrm{~km}$ width (Ayadi and Bargaoui, 1998). The coastline of the Rades - Hammam lif, is about $10 \mathrm{Km}$ of length and $5 \mathrm{~km}$ of width; centered by the Meliane River, Rades city in the North and Hammam lif city in the South. In the Gulf of Tunis, the distribution of sediment is managed by the circulation of water in the Mediterranean and the local wind-induced currents and waves as well as by the contributions from rivers and streams (Brahim et al., 2015). The direction axis of the Gulf of Tunis is NESW (Rais, 1999). The main swell directions in the Gulf of Tunis are those from the NNE to NE direction, with a North-South coastal drift (El Arrim, 1996). The Gulf of Tunis area is characterized by Oligo-Miocene geological origin which consists of a series of clayey sandstones (Ben Ayed et al., 1983; Brahim et al., 2015), with Pliocene hills made up of a series of green clays (M'âamri, 1998; Brahim et al., 2015) and Quaternary plains containing a rich gray sand layer, an alluvium formed by sandy clays, sands and gravels (Jouirou, 1982; Brahim et al., 2015).

After the construction of the dams of El Kbir in 1920, Bir M'Cherga in 1971 and Lahma in 2002, the sediments input into the Gulf of Tunis decreased from $3.310^{6}$ to $2.210^{6}$ tons/year (Sliti, 1990; El Arrim, 1996; Saïdi et al., 2013). This reduction affects the solid and liquid inputs to the Gulf of Tunis containing the discharged polluted waters (Added et al., 2003; Khadhar et al., 2018; Kabouchi et al., 2020).

The Meliane River is the focal point of different human activities. It is strongly affected by the urban agglomeration as well as by the concentration of the industrial and agriculture activities. It is also considered as the exit point of the wastes of the industrial zones (e.g., electronic and mechanic industries, chemical manufacturing plants), food factories (e.g., cake factory, tomato-canning factories), municipal wastes (e.g., slaughterhouse, sewage treatment plants) and pharmaceutical society. According to the National Office of Assessment (ONAS) (2008), the wastewater discharged into the Meliane River represents $59,840 \mathrm{~m}^{3} / \mathrm{d}$ from the urban discharges, and about 


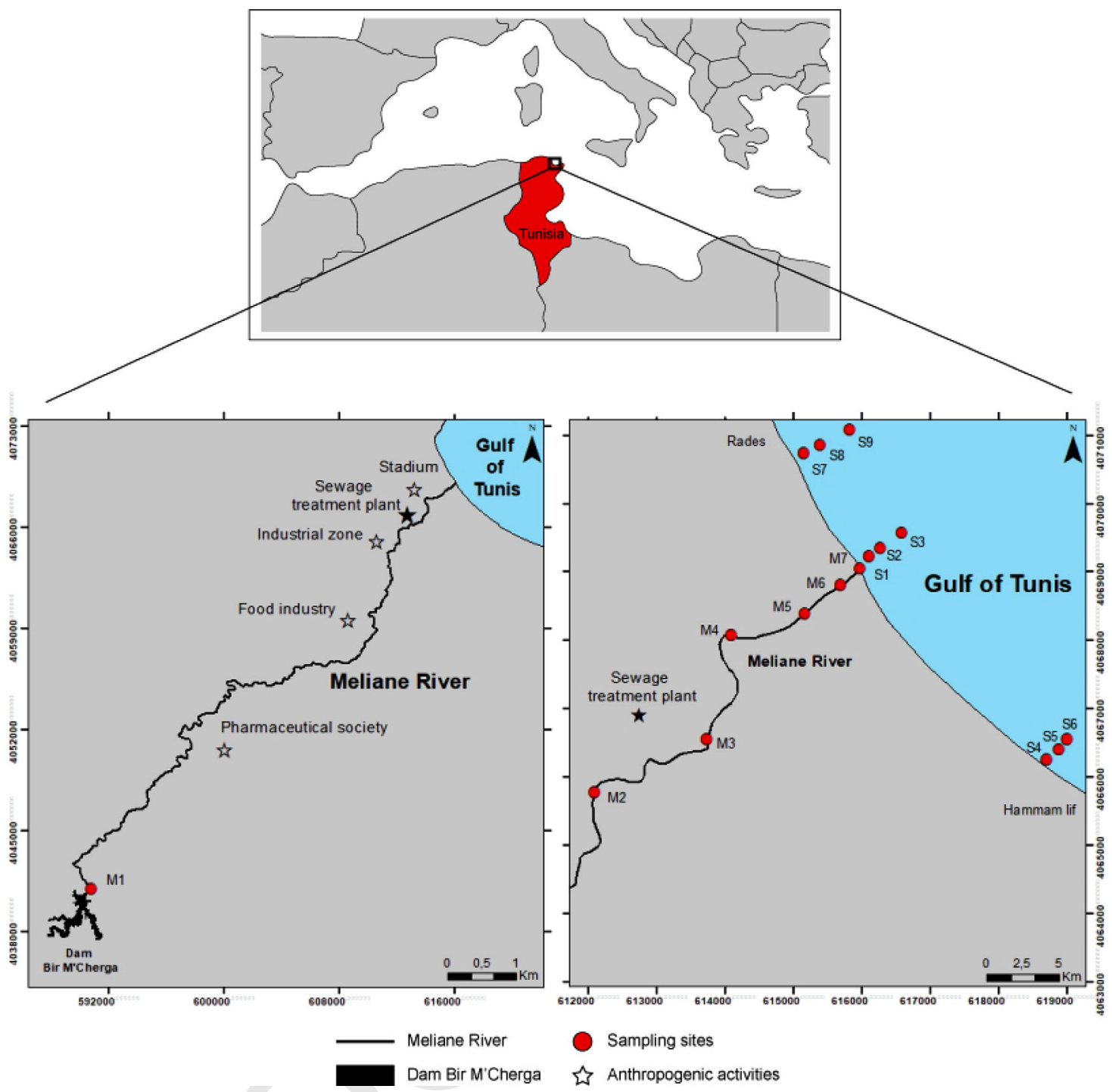

Figure 1. Study area and samples sites in the Meliane River and marine stations on the Gulf of Tunis.

$382 \mathrm{~m}^{3} / \mathrm{d}$ of untreated water from the industrial discharges (ONAS, 2008). Domestic wastes come essentially from the Rades sewage treatment plant, which flows directly into the Gulf of Tunis. In addition, this area is considered as a container for several agricultural wastes, along with urban disposals of the Meliane sewage treatment plant, Mornag sewage treatment plant and the gravel station of Ben Arous (Agence nationale de Protection de l'Environnement [ANPE], 2014; Khabouchi et al., 2020). Thereby, the Meliane River crosses densely populated area and affected by several types of industries and its sediments certainly act as an important sink for trace metals, which releases directly and permanently into the Gulf of Tunis, as well as the effluents of waste treatment plant of "Sud Meliane" and some treated or non-treated industrial discharges (Ben Charrada, 1997; Ayari and afli, 2008). The Rades - Hammam lif coastline is known, since 1994 , by a high nutrient concentration and turbidity caused by the flows of the Meliane River (Souissi et al., 2000; Yahia et al., 2004; Ben Lamine et al., 2012).

\section{Materials and methods}

The distribution of sampling localization is shown in Figure 1. In this study, sixteen samples of surface sediment were collected. Seven surface sediment samples were collected from the upstream to the downstream of the Meliane River. They were collected at the upstream of the Meliane River, before the sewage treatment plant, and at the downstream part of the watercourse. The rest were collected from the marine stations of the Gulf of Tunis coast along three radials. Those radials, with depths of 3,5 and 7 meters, were 
taken from the front part of the Meliane River, at Rades in the north, and Hammam-lif in the south.

The Meliane River samples were harvested using a stainless-steel shovel; while the marine surface sediments were harvested using a Van Veen grab. The sediments were immediately placed in polyethylene plastic bags and stored at $-4{ }^{\circ} \mathrm{C}$. In the laboratory, the samples were lyophilized. Then, they were homogenized and sieved. A granulometric analysis was carried out for 20 minutes on a series of AFNOR-type sieves using a RoTap Sieve Shaker. The total organic matter was determined by the method of ignition weight loss and $1 \mathrm{~g}$ of surface sediments was incinerated at $450{ }^{\circ} \mathrm{C}$ for 5 hours. In order to ensure the quality control of the results (Table 1), a sediment reference sample (Sed IAEA, 405) was utilized in each series of the analyses. Subsequently, the analysis of the total contents of $\mathrm{Cd}, \mathrm{Cu}, \mathrm{Pb}, \mathrm{Zn}, \mathrm{Ni}, \mathrm{Cr}, \mathrm{Mn}$ and $\mathrm{Al}$ and chemical speciation by sequential extraction of surface sediments samples were performed.

Total amounts of $\mathrm{Cd}, \mathrm{Cu}, \mathrm{Pb}, \mathrm{Zn}, \mathrm{Ni}, \mathrm{Cr}$ and $\mathrm{Mn}$ were determined using the microwave dissolution technique. The digestion of surface sediments was specified using $0.25 \mathrm{~g}$ of sample put in Teflon reactors and mixed with $5 \mathrm{ml}$ of nitric acid and $2 \mathrm{ml}$ of hydrofluoric acid. After mineralization in the microwave (Milestone ETHOS), $0.8 \mathrm{~g}$ of boric acid was added. The dissolved samples were diluted with ultrapure water up to $50 \mathrm{ml}$. The $\mathrm{Al}$ was determined by adding $1 \mathrm{~g}$ of sample, with a mixture of hydrofluoric and perchloric acid (2/3-1/3), and using a triacid attack. This mixture was heated until almost total evaporation. Then, it was recovered by adding $5 \%$ nitric acid and heated again till boiling. After cooling, the volume of the solution was adjusted.

The sequential extraction (Tessier et al., 1979) is a method which consists in extracting five fractions: the "exchangeable" fraction, the "carbonate-bound" fraction, the "reducible or Fe/Mn oxide-bound "fraction, the" oxidizable or organic matter-bound and sulfide "fraction, and the "residual" fraction. Its different steps are described below:

- Extracting exchangeable fraction (F1) $1 \mathrm{~g}$ of sediment with magnesium chloride.

- Extracting carbonate-bound (F2) fraction using Sodium acetate.

- Extracting reducible fraction (F3) with Hydroxylammonium chloride in acid acetic.

- Extracting oxidizable fraction (F4) with Nitric acid, Hydrogen peroxide and then Ammonium acetate.

- Extracting residual fraction (F5) using Nitric and Perchloric acids.
Table 1. Results of standard sediment reference material IAEA-405.

\begin{tabular}{lcc}
\hline Metal $\left(\mu \mathrm{g} \cdot \mathrm{g}^{-1}\right)$ & IAEA 405 & This study \\
\hline $\mathrm{Cd}$ & $0.68-0.78$ & 0.75 \\
$\mathrm{Cu}$ & $46-48.9$ & 49.79 \\
$\mathrm{~Pb}$ & $72.6-77$ & 74.36 \\
$\mathrm{Zn}$ & $272-286$ & 282.21 \\
$\mathrm{Ni}$ & $31.1-33.9$ & 33.65 \\
$\mathrm{Cr}$ & $80-88$ & 78.86 \\
$\mathrm{Mn}$ & $484-506$ & 504.68 \\
$\mathrm{Al}$ & $72,700-83,100$ & 85825 \\
\hline
\end{tabular}

Each sample was shaken in a shaking incubator. The extractions were afterwards conducted in $50 \mathrm{ml}$ polyethylene tubes. The phase-separation sediment-solution was obtained by centrifugation for 20 minutes at $5000 \mathrm{t} / \mathrm{mn}$.

\section{Statistical analysis}

The relationships between the total trace metals were tested using the XLSTAT (2019) software applying the correlation matrix, the principal component analysis (PCA) and the relation between elements and samples. A statistical treatment was applied on all the elements and samples.

\section{Assessment of sediment contamination}

The classifications of pollution indicators and risk assessments are explained in Tables 2 and 3.

The contamination factor (CF) was measured according to Hakanson (1980) using the following formula:

$$
C F=\frac{C_{m}}{C_{B}}
$$

where $C_{m}$ and $C_{B}$ are the concentrations of the element in the sediment sample and background, respectively.

The M1 station is situated near the downstream of the Bir M'Cherga Dam used for water drinking, fishery and irrigation. In this study, we used the M1 of the Meliane River as uncontaminated station.

To estimate the sources of metals and to assess the impact of anthropogenic activities, a formula of the enrichment factor (EF) (Hilton et al., 1985; Sutherland, 2000; Cukrov et al., 2011; Ahmedat et al., 2018) was measured according to the following equation:

$$
E F=\frac{\left(\mathrm{Cm} /{ }_{C A l}\right) S}{(\mathrm{Cm} / \mathrm{CAl}) B}
$$

where the Aluminum ( $\mathrm{Al}$ ) is considered as a natural element of reference; $\left(\mathrm{C}_{\mathrm{m}} / \mathrm{C}_{\mathrm{Al}}\right) \mathrm{S}$ denotes the ratio between the concentration of the element " $\mathrm{m}$ " and that of $\mathrm{Al}$ in the sediment sample and $\left(\mathrm{C}_{\mathrm{m}} / \mathrm{C}_{\mathrm{Al}}\right) \mathrm{B}$ 
Table 2. Classification of contamination factor (CF), enrichment factor (EF), and ecological risk (RI and MRI).

\begin{tabular}{lll}
\hline Contamination factor (CF) & \multicolumn{1}{c}{ Enrichment factor (EF) } & Ecological risk assessment (RI and MRI) \\
\hline $\mathrm{CF}<1$, low contamination & $\mathrm{EF}<2$ : deficiency to low enrichment & $\mathrm{MRI}<150$ low ecological risk \\
$1<\mathrm{CF}<3$, moderate contamination & $2<\mathrm{EF}<5$ : moderate enrichment & $150<\mathrm{RI}-\mathrm{MRI}<300$, moderate ecological risk \\
$3<\mathrm{CF}<6$, considerable contamination & $5<\mathrm{EF}<20$ : significant enrichment & $300<\mathrm{RI}-\mathrm{MRI}<600$, high ecological risk \\
$6>\mathrm{CF}$, very high contamination & $20<\mathrm{EF}<40$ : very high enrichment & $\mathrm{RI}-\mathrm{MRI} \geq 600$, significantly high ecological risk
\end{tabular}

Table 3. Classifications of individual contamination factor (ICF), global contamination factors (GCF), risk assessment code (RAC) and modified risk assessment code (mRAC).

\begin{tabular}{lll}
\hline ICF and GCF & & RAC and mRAC \\
\hline $\mathrm{ICF}<0$ & Low risk & $<1$ \\
$\mathrm{GCF}<6$ & Moderate & $1 \%<\mathrm{RAC}<10 \%$ \\
$1<\mathrm{ICF}<3$ & & $11 \%<\mathrm{RAC}<30 \%$ \\
$6<\mathrm{GCF}<12$ & Considerable & No risk \\
$3<\mathrm{ICF}<6$ & High contamination & $31 \%<\mathrm{RAC}<50 \%$ \\
$12<\mathrm{GCF}<24$ & Medium risk \\
$\mathrm{ICF}>6$ & & RAC $>50 \%$ \\
$\mathrm{GCF}>24$ & & High risk \\
\hline
\end{tabular}

designates the ratio between the concentration of the element " $\mathrm{m}$ " and that of $\mathrm{Al}$ in the background.

According to Hakanson (1980), the potential ecological risk index was calculated as follows:

$$
R I=\sum_{i=1}^{n} E_{r}^{i}=\sum_{i=1}^{n} T_{r}^{i} \times C F^{i}
$$

where $E_{r}^{i}$ is the potential ecological risk index of an individual element, $T_{r}^{i}$ corresponds to the toxicity coefficient for the metal "i" and $C F^{i}$ refers to the contamination factor of each element (Soliman et al., 2015; Zhang et al., 2016, 2018).

A modified ecological risk index (MRI) using the enrichment factor (EF) was suggested by Brady et al. (2015); Gargouri et al. (2018), as follows:

$$
M R I=\sum_{i=1}^{n} E_{r}^{i}=\sum_{i=1}^{n} T_{r}^{i} \times E F^{i}
$$

The individual contamination factor (ICF) and the global contamination factor (GCF) were calculated according to Ikem et al. (2003); Chen et al. (2013). The ICF was obtained by dividing of the exchangeable, the carbonates, the reducible and the organic applying the residual fraction. The GCF was determined by summing the ICF of all trace elements for each sample. The ICF and GCF were calculated as follows:

$$
\begin{gathered}
I C F_{m}=\frac{C_{\text {non-resudial }}}{C_{\text {residual }}} \\
G C F=\sum_{i=1}^{n} C F_{i}
\end{gathered}
$$

The risk assessment code (RAC) was computed using the percentage of exchangeable metals and carbonate bound in the sediments (Perin et al., 1985; Jain, 2004; Ghrefat and Yusuf, 2006; Chen et al, 2013). The RAC was used to assess the bioavailability and the mobility of metals. The applied equation is written below:

$$
R A C=\frac{F 1+F 2}{C_{t}} \times 100
$$

where F1 and F2 are the concentrations of the metal in exchangeable and carbonate-bound fractions, respectively and $C_{t}$ is the total concentration of the metal.

A modified risk assessment code (mRAC) was measured using the following equation (Saeedi and Jamshidi-Zanjani, 2015):

$$
m R A C=\frac{\sum_{i=1}^{n} T_{i} R A C_{i}}{\sum_{i=1}^{n} \operatorname{Tr} i}
$$

where RAC is the percentage of each metal in the exchangeable and carbonate-bound fractions, Tri represents toxicity coefficient of metal according to Hakanson (1980), and $\mathrm{n}$ is the number of metals (Saeedi et al., 2015).

\section{Results and discussion}

\section{Grain-size distribution}

The grain-size distribution was determined using the GRADISTAT program. The distribution pattern of the sand, silt and clay fractions showed a significant variation characterized by the dominance of the sand fraction (Figure 2). The Meliane River had the highest percentage of sand with an average content of $98.6 \%$. This percentage ranged from $96.38 \%$ to $99.99 \%$ 


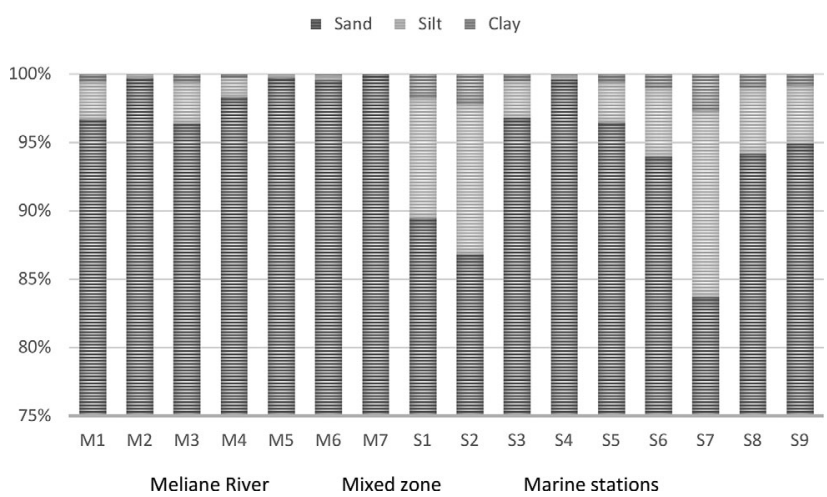

Figure 2. Distribution of grain size (\%) in the surface sediments of the Meliane River and marine stations of the Gulf of Tunis.

recorded in the stations near the sewage treatment plant (M3) and the mouth of the Meliane River (M7), respectively. In marine sediments, the sandy fraction varied between $83.68 \%$ and $99.57 \%$. The highest percentage was recorded in the Hammam-lif city in the south (S4) and the lowest in stations of the Rades (S7) in the north.

\section{Organic matter}

The percentages of organic matter range from 1.15\% to $29.9 \%$, in the Meliane River, and varied between $1.8 \%$ and $11.9 \%$ in the marine stations (Figure 3). In Meliane River, the highest recorded percentage was at the downstream part and the lowest in the mixed zone of the Meliane River. In the marine stations of the Gulf of Tunis coast, the highest percentages were located in front of the Meliane River and the lowest value was obtained in the Hammam-lif city. This variation is related to discharges of sewage treatment plant located near the Meliane River.

This variation results from the discharges of sewage treatment plant located near the Meliane River and the physicochemical parameters changes observed in the area extending from the salt-freshwater mixed region to the marine stations.

\section{Total trace metals}

Trace metal concentrations of surface sediments are listed in Table 4. In the Meliane River, the total concentrations of trace metals in the surface sediments ranged from $0.26 \mu \mathrm{g} \mathrm{g}^{-1}$ to $0.97 \mu \mathrm{g} \mathrm{g}^{-1}$ for $\mathrm{Cd}$, from $2.16 \mu \mathrm{g} \mathrm{g}^{-1}$ to $205.7 \mu \mathrm{g} \mathrm{g} \mathrm{g}^{-1}$ for $\mathrm{Cu}$, from 5.26 to $31.12 \mu \mathrm{g} \mathrm{g}^{-1}$ for $\mathrm{Pb}$, from $29.25 \mu \mathrm{g} \mathrm{g}^{-1}$ to $317.93 \mu \mathrm{g}$ $\mathrm{g}^{-1}$ for $\mathrm{Zn}$, from $32.83 \mu \mathrm{g} \mathrm{g}^{-1}$ to $50.27 \mu \mathrm{g} \mathrm{g}^{-1}$ for $\mathrm{Ni}$, from $29 \mu \mathrm{g} \mathrm{g}^{-1}$ to $78.97 \mu \mathrm{g} \mathrm{g}^{-1}$ for $\mathrm{Cr}$, and from $120.4 \mu \mathrm{g} \mathrm{g}^{-1}$ to $1203.51 \mu \mathrm{g} \mathrm{g}^{-1}$ for $\mathrm{Mn}$.
The spatial distribution of trace metals in the surface sediment of the Meliane River (Figure 4) shows that, from upstream to downstream (M1 to M7), the highest concentrations of $\mathrm{Cd}, \mathrm{Cu}, \mathrm{Pb}, \mathrm{Zn}$ and $\mathrm{Cr}$ were recorded in the downstream part after the sewage treatment plant (station M5). However, for $\mathrm{Ni}$ and $\mathrm{Mn}$, the highest recorded values were in the upstream (station M1) near the dam of Bir M'Cherga. Except $\mathrm{Cd}$ and $\mathrm{Mn}$, the lowest concentration of $\mathrm{Cu}, \mathrm{Pb}, \mathrm{Zn}$, $\mathrm{Ni}$ and $\mathrm{Cr}$ were observed in the mouth of the Meliane River (station M7).

The spatial distribution of trace metals in surface sediments at marine stations of the Gulf of Tunis between Rades and Hammam-lif cities is shown in (Figure 4). Concentrations of trace metals in these sediments vary between $0.22 \mu \mathrm{g} \mathrm{g}^{-1}$ and $0.55 \mu \mathrm{g} \mathrm{\textrm {g } ^ { - 1 }}$ for $\mathrm{Cd}$, between $1.55 \mu \mathrm{g} \mathrm{g}^{-1}$ and $12.28 \mu \mathrm{g} \mathrm{g}^{-1}$ for $\mathrm{Cu}$, between 4.9 and $11.85 \mu \mathrm{g} \mathrm{g}^{-1}$ for $\mathrm{Pb}$, between $35.56 \mu \mathrm{g}$ $\mathrm{g}^{-1}$ and $99.89 \mu \mathrm{g} \mathrm{g}^{-1}$ for $\mathrm{Zn}$, between $30.11 \mu \mathrm{g} \mathrm{g}^{-1}$ and $43.68 \mu \mathrm{g} \mathrm{g}^{-1}$ for $\mathrm{Ni}$, between $30.14 \mu \mathrm{g} \mathrm{g}^{-1}$ and $52.24 \mu \mathrm{g} \mathrm{g}^{-1}$ for $\mathrm{Cr}$, and between $128.54 \mu \mathrm{g} \mathrm{g}^{-1}$ and $228.7 \mu \mathrm{g} \mathrm{g}^{-1}$ for $\mathrm{Mn}$. The highest concentrations of $\mathrm{Pb}, \mathrm{Zn}, \mathrm{Ni}, \mathrm{Cr}$ and $\mathrm{Mn}$ were obtained in the stations in front of the Meliane River. The highest concentrations of $\mathrm{Cd}$ and $\mathrm{Cu}$ were seen in the marine stations of the Rades city in the north. Besides, a relatively high concentration was observed at stations in front of the Meliane River and the lowest concentrations were generally provided at the Hammam-lif in the south.

The spatial distribution of the total trace metals, in surface sediments, is characterized by trace metals with significant concentrations in the Meliane River due to its discharges and the decrease in the marine stations of the Gulf of Tunis between Rades and Hammam-lif cities. The distribution of trace metals in the surface sediments is related to the transport of an important content of sediments and wastewater discharged by the Meliane River and the north-south shoreline drifts in the Gulf of Tunis.

\section{Pollution indicators}

The contamination factor (CF) values ranged from 0.58 to 2.55 for $\mathrm{Cd}$; from 0.03 to 4.37 for $\mathrm{Cu}$; from 0.81 to 5.12 for $\mathrm{Pb}$; from 0.36 to 3.87 for $\mathrm{Zn}$; from 0.6 to 0.87 for $\mathrm{Ni}$; from 0.55 to 1.50 for $\mathrm{Cr}$, and from 0.1 to 0.24 for $\mathrm{Mn}$. According to the classification of Hakanson (1980), the CF values of $\mathrm{Cu}, \mathrm{Ni}$ and $\mathrm{Mn}$ indicate a low contamination $(\mathrm{CF}<1)$ in all stations, except for $\mathrm{Cu}$ in the downstream part zone (station M5). The $\mathrm{CF}$ of $\mathrm{Cd}$ was moderate in the Meliane 
COLOR Online I $B \& W$ in Print

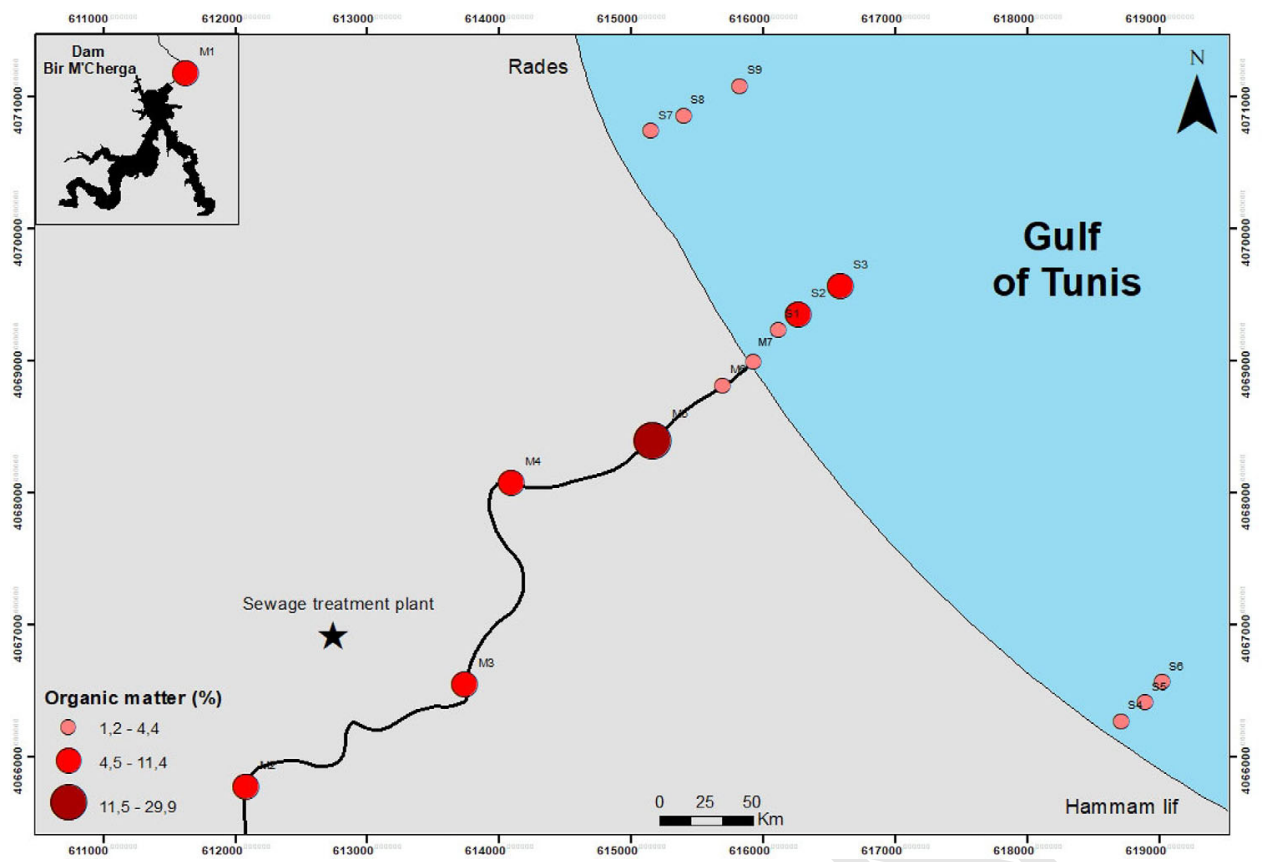

Figure 3. Spatial distribution of organic matter in the Meliane River and marine stations of the Gulf of Tunis.

Table 4. Trace metals concentrations $\left(\mu \mathrm{g} \mathrm{g}^{-1}\right)$ in the surface sediments of the Meliane River and marine stations of the Gulf of Tunis.

\begin{tabular}{lcrrrrrr}
\hline Stations & $\mathrm{Cd}$ & \multicolumn{1}{c}{$\mathrm{Cu}$} & \multicolumn{1}{c}{$\mathrm{Pb}$} & \multicolumn{1}{c}{$\mathrm{Zn}$} & $\mathrm{Ni}$ & $\mathrm{Cr}$ & $\mathrm{Mn}$ \\
\hline M1 & 0.38 & 47.04 & 6.08 & 82.17 & 50.27 & 52.72 & 1203.51 \\
M2 & 0.49 & 37.92 & 16.12 & 191.28 & 34.92 & 63.73 & 187.29 \\
M3 & 0.42 & 20.05 & 19.46 & 111.61 & 33.88 & 43.54 & 228.66 \\
M4 & 0.26 & 18.84 & 8.46 & 69.71 & 33.39 & 41.35 & 287.85 \\
M5 & 0.97 & 205.70 & 31.12 & 317.93 & 37.59 & 78.97 & 196.13 \\
M6 & 0.91 & 3.81 & 7.83 & 211.90 & 34.17 & 32.08 & 120.40 \\
M7 & 0.83 & 2.16 & 5.26 & 29.25 & 32.83 & 29.00 & 124.10 \\
S1 & 0.36 & 2.24 & 10.63 & 61.40 & 30.11 & 44.77 & 149.08 \\
S2 & 0.33 & 2.62 & 7.92 & 62.67 & 43.68 & 48.80 & 188.70 \\
S3 & 0.52 & 3.78 & 11.85 & 99.89 & 30.94 & 59.24 & 228.17 \\
S4 & 0.22 & 1.55 & 5.02 & 35.56 & 31.84 & 30.14 & 161.10 \\
S5 & 0.24 & 2.22 & 4.90 & 46.95 & 35.39 & 30.34 & 159.17 \\
S6 & 0.25 & 2.53 & 5.75 & 56.99 & 35.98 & 52.89 & 180.30 \\
S7 & 0.55 & 1.99 & 6.68 & 77.97 & 33.30 & 44.95 & 151.11 \\
S8 & 0.37 & 12.28 & 6.62 & 46.87 & 34.78 & 36.71 & 128.54 \\
S9 & 0.43 & 2.27 & 6.61 & 57.92 & 35.07 & 41.93 & 137.46 \\
\hline
\end{tabular}

River site and low in the marine stations, except at S3, $\mathrm{S} 7$ and $\mathrm{S} 9$. The $\mathrm{CF}$ values of $\mathrm{Pb}$ and $\mathrm{Zn}$ showed considerable contamination in the Meliane River and a moderate contamination in the marine stations. Moreover, the $\mathrm{CF}$ for $\mathrm{Cr}$ was low in the Meliane River and marine stations, except M1, M5 and S3 which were moderate (Figure 5).

The enrichment factor (EF) values varied from 1.09 to 83.53 for $\mathrm{Cd}$; from 0.13 to 6.11 for $\mathrm{Cu}$; from 1 to 33 for $\mathrm{Pb}$; from 1 to 44.52 for $\mathrm{Zn}$ : from 0.84 to 24.92 for $\mathrm{Ni}$; from 1.24 to 20.99 for $\mathrm{Cr}$; and from 0.19 to 3.93 for $\mathrm{Mn}$. The EF values indicated a low enrichment $(\mathrm{EF}<2)$ of $\mathrm{Mn}$ and $\mathrm{Cu}$ for the majority of the stations in the study area, except M5 of $\mathrm{Cu}$ and M7 of $\mathrm{Mn}$ which were moderate. The $\mathrm{EF}$ values of $\mathrm{Pb}, \mathrm{Ni}$ and $\mathrm{Cr}$ were identified to be low-to-moderate for marine stations. But, in the sites upstream of the Meliane River, these metals had significant EF values. The EF values of $\mathrm{Cd}$ and $\mathrm{Zn}$ were low-to-moderate, in the upstream, and extremely high in the downstream. For marine stations, they were identified to be moderate-to-significant (Table 5). The results of RI varied from 28.96 to 134.72 (Table 4). The RI values show a low risk in the Meliane River as well as the marine stations. The modified ecological risk index (MRI) values oscillated between 5.58 and 2858.34. In the Meliane River, the upstream MRI values were low, while MRI values indicated a very high risk in the downstream part and the mixed zone. In fact, at the marine stations, the MRI was moderate.

\section{Statistical analysis}

The positive correlations between $\mathrm{Cd}(\mathrm{r}=0.70), \mathrm{Cu}$ $(\mathrm{r}=0.79), \mathrm{Pb}(\mathrm{r}=0.82)$ and $\mathrm{Cr}(\mathrm{r}=0.66)$ with $\mathrm{Zn}$ may indicate similar and/or a common origin (Table 7).

Principal component analysis (PCA) was applied for 16 stations and 7 parameters (Figure 6). PCA allowed the discrimination of two axes (F1 and F2), which accumulate $80.01 \%$ of the total variance. In the variable space, F1, defined by a positive charge of the contents of $\mathrm{Cd}, \mathrm{Cu}, \mathrm{Pb}, \mathrm{Zn}$, and $\mathrm{Cr}$, represents the axis of $52.84 \%$ of the variance. The $\mathrm{F} 1$ axis presents the origin of pollution. The F2, characterized by 
741

742 74 : COLOR $744_{\text {Print }}^{B \& W}$

745

746

747

748

749

750

751

752

753

754

755

756

757

758

759

760

761

762

763

764

765

766

767

768

769

770

771

772

773

774

775

776

777

778

779

780

781

782

783

784

785

786

787

788

789

790

791

792

793

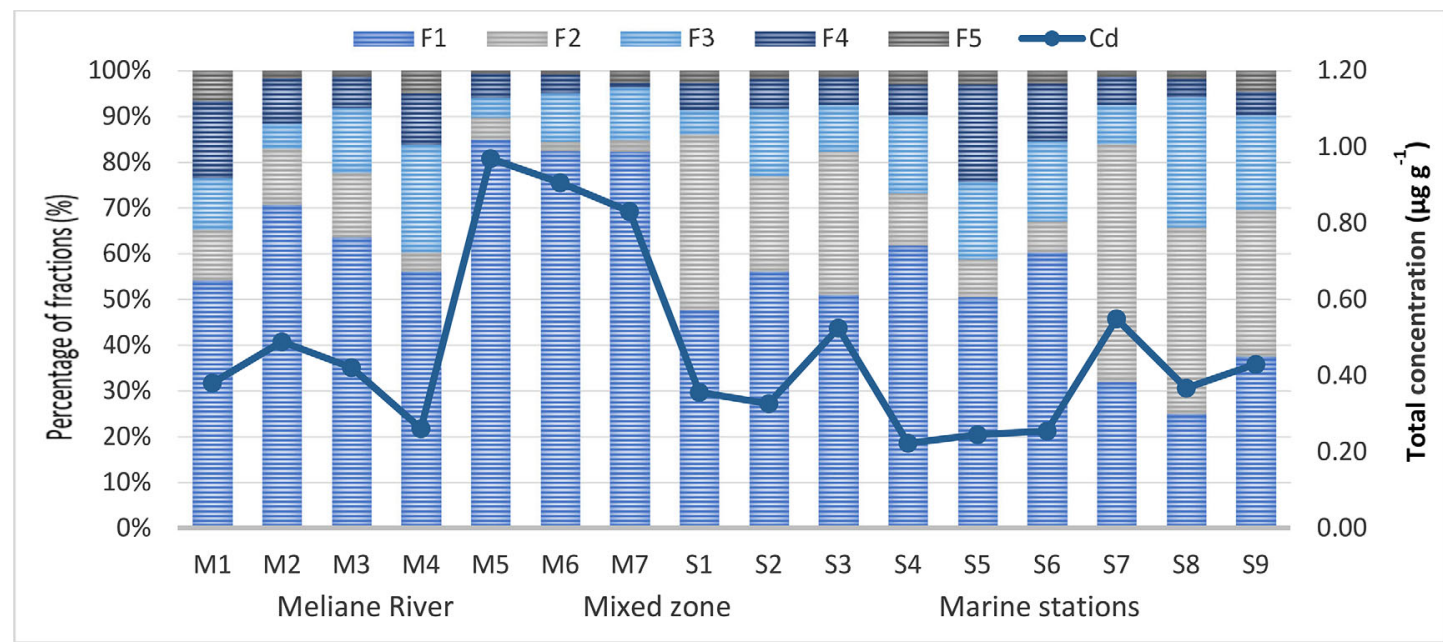

794

795

796

797

798

799

800

801

802

803

804

805

806

807

808

809

810

811

812

813

814

815

816

817

818

819

820

821

822

823

824

825

826

827

828

829

830

831

832

833

834

835

836

837

838

839

840

841

842

843

844

845

846 
847

848

849

COLOR

B\&W in

Print

852

853

854

855

856

857

858

859

860

861

862

863

864

865

866

867

868

869

870

871

872

873

874

875

876

877

878

879

880

881

882

883

884

885

886

887

888

889

890

891

892

893

894
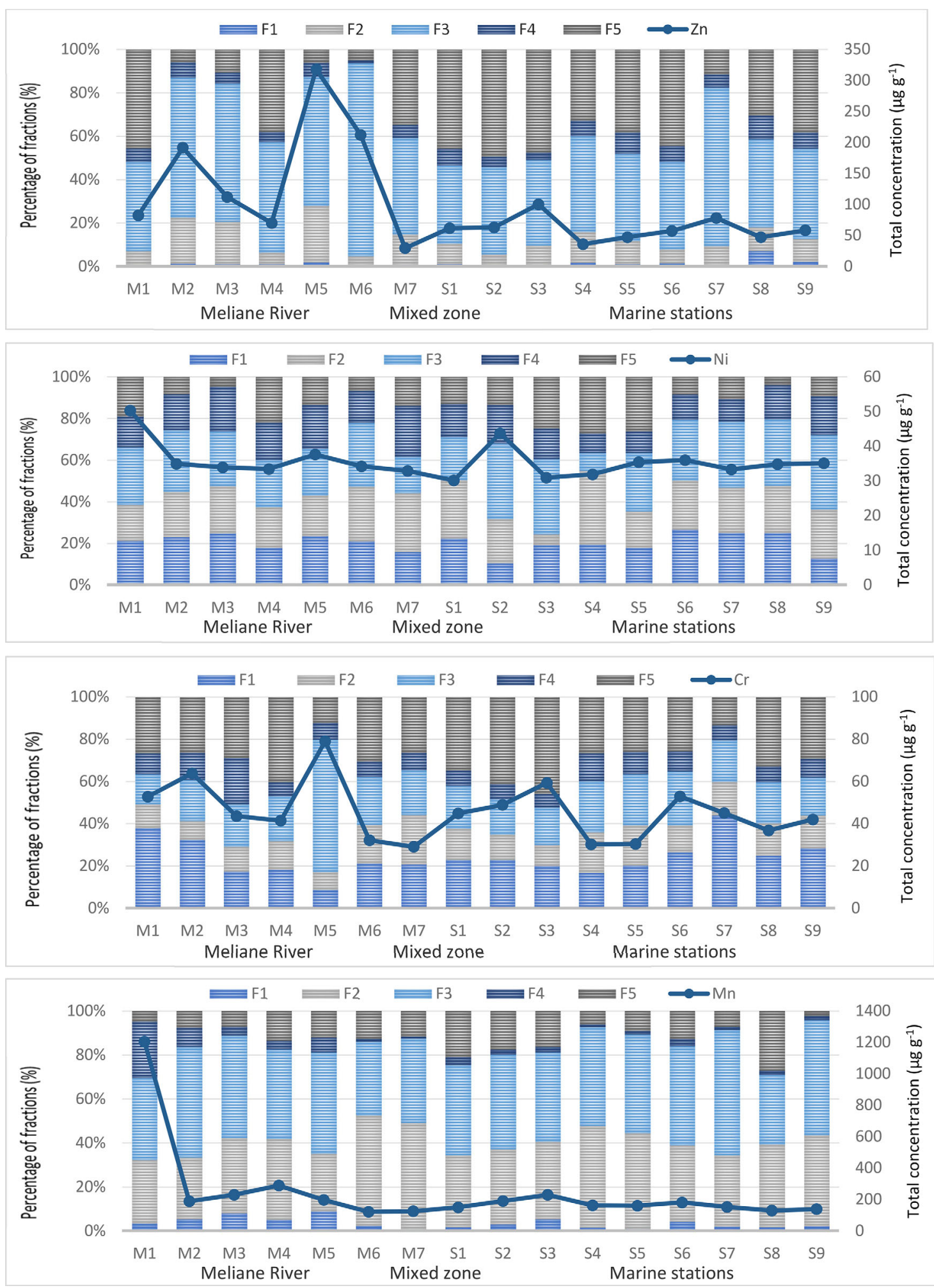

Figure 4. Continued.

positive contributions of $\mathrm{Ni}$ and $\mathrm{Mn}$, shows the axis of $27.17 \%$ of the variance

The corresponding analysis (Figure 7) depicts the relations between the stations and the different parameters used in order to clarify this link. The loading plot of two factors shows the presence of three groups resulting from the quality and nature of water; river and marine stations and wastewater discharge. 
95 EOLOR

$956_{\text {Print }}^{\text {B in }}$

957

958

959

960

961

962

963

964

965

966

967

968

969

970

971

972

973

974

975

976

977

978

979

980

981

982

983

984

985

986

987

988

989

990

991

992

993

994

995

996

997

998

999

1000

1001

1002

1003

1004

1005

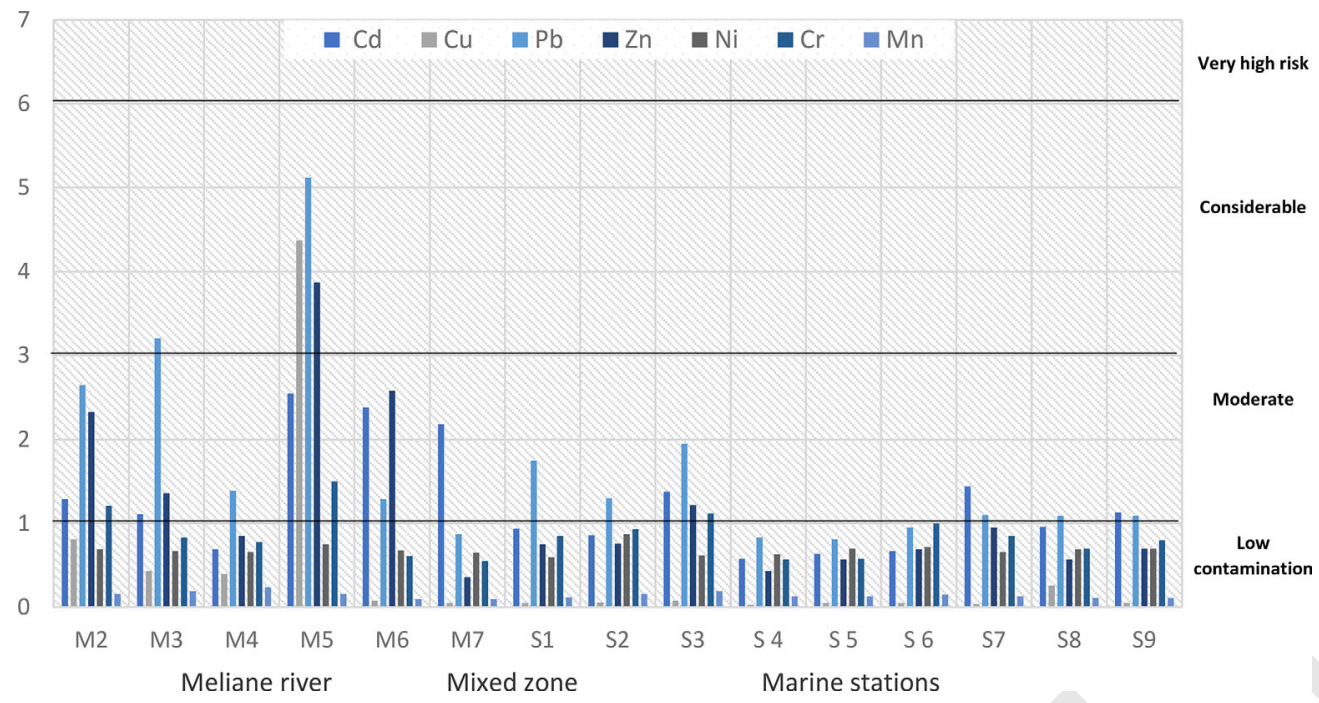

Figure 5. Contamination factor (CF) of the surface sediments of the Meliane River and marine stations of the Gulf of Tunis.

Table 5. Enrichment factors (EF) of the surface sediments of the Meliane River and marine stations of the Gulf of Tunis.

\begin{tabular}{lrrrrrrr}
\hline Stations & \multicolumn{1}{c}{$\mathrm{Cd}$} & $\mathrm{Cu}$ & $\mathrm{Pb}$ & $\mathrm{Zn}$ & $\mathrm{Ni}$ & $\mathrm{Cr}$ & $\mathrm{Mn}$ \\
\hline $\mathrm{M} 2$ & 1.55 & 0.97 & 3.19 & 2.80 & 0.84 & 1.46 & 0.19 \\
M3 & 1.75 & 0.67 & 5.04 & 2.14 & 1.06 & 1.30 & 0.30 \\
M4 & 1.09 & 0.64 & 2.21 & 1.35 & 1.05 & 1.24 & 0.38 \\
M5 & 3.57 & 6.11 & 7.16 & 5.41 & 1.05 & 2.09 & 0.23 \\
M6 & 41.15 & 1.40 & 22.22 & 44.52 & 11.73 & 10.51 & 1.73 \\
M7 & 83.35 & 1.75 & 33.00 & 13.58 & 24.92 & 20.99 & 3.93 \\
S1 & 5.10 & 0.26 & 9.53 & 4.07 & 3.26 & 4.63 & 0.67 \\
S2 & 2.59 & 0.17 & 3.92 & 2.30 & 2.62 & 2.79 & 0.47 \\
S3 & 2.30 & 0.13 & 3.25 & 2.03 & 1.03 & 1.88 & 0.32 \\
S4 & 6.09 & 0.34 & 8.60 & 4.51 & 6.60 & 5.95 & 1.39 \\
S5 & 4.97 & 0.36 & 6.22 & 4.41 & 5.43 & 4.44 & 1.02 \\
S6 & 2.62 & 0.21 & 3.70 & 2.71 & 2.80 & 3.93 & 0.59 \\
S7 & 5.95 & 0.17 & 4.53 & 3.91 & 2.73 & 3.51 & 0.52 \\
S8 & 7.39 & 2.00 & 8.33 & 4.37 & 5.30 & 5.33 & 0.82 \\
S9 & 5.86 & 0.25 & 5.64 & 3.66 & 3.62 & 4.13 & 0.59 \\
\hline
\end{tabular}

Table 6. Potential ecological risk (RI), and modified potential ecological risk (MRI) in the surface sediments of the Meliane River and marine stations of the Gulf of Tunis.

\begin{tabular}{lrr}
\hline Stations & Rl & MRI \\
\hline M2 & 64.22 & 77.34 \\
M3 & 57.92 & 91.27 \\
M4 & 35.52 & 56.35 \\
M5 & 134.72 & 188.37 \\
M6 & 85.65 & 1478.42 \\
M7 & 74.91 & 2858.34 \\
S1 & 42.64 & 232.34 \\
S2 & 39.67 & 119.43 \\
S3 & 58.28 & 97.33 \\
S4 & 26.71 & 278.15 \\
S5 & 28.96 & 223.55 \\
S6 & 31.50 & 123.27 \\
S7 & 55.10 & 227.11 \\
S8 & 41.22 & 315.61 \\
S9 & 45.48 & 235.92 \\
\hline
\end{tabular}

This discrimination of station groups is essentially reflected in the following observations:

- The first group (the GI group) includes the stations located upstream (M1), taken at the exit of Bir M 'Cherga Dam. It involves $\mathrm{Ni}$ and $\mathrm{Mn}$.
Table 7. Correlations matrix of elements in the surface sediments of the Meliane River and marine stations of the Gulf of Tunis.

\begin{tabular}{llllllll}
\multicolumn{7}{l}{ of the Meliane River and marine stations of the Gulf of Tunis. } & Q14 \\
\cline { 1 - 7 } Elements & $\mathrm{Cd}$ & $\mathrm{Cu}$ & $\mathrm{Pb}$ & $\mathrm{Zn}$ & $\mathrm{Ni}$ & $\mathrm{Cr}$ & $\mathrm{Mn}$ \\
\hline $\mathrm{Cd}$ & 1 & & & & & & \\
$\mathrm{Cu}$ & 0.52 & 1 & & & & & \\
$\mathrm{~Pb}$ & 0.49 & 0.84 & 1 & & & & \\
$\mathrm{Zn}$ & 0.70 & 0.79 & 0.82 & 1 & & & \\
$\mathrm{Ni}$ & -0.08 & 0.26 & -0.03 & 0.08 & 1 & & \\
$\mathrm{Cr}$ & 0.26 & 0.73 & 0.75 & 0.66 & 0.27 & 1 & \\
$\mathrm{Mn}$ & -0.15 & 0.16 & -0.08 & -0.03 & 0.78 & 0.21 & 1 \\
\hline
\end{tabular}

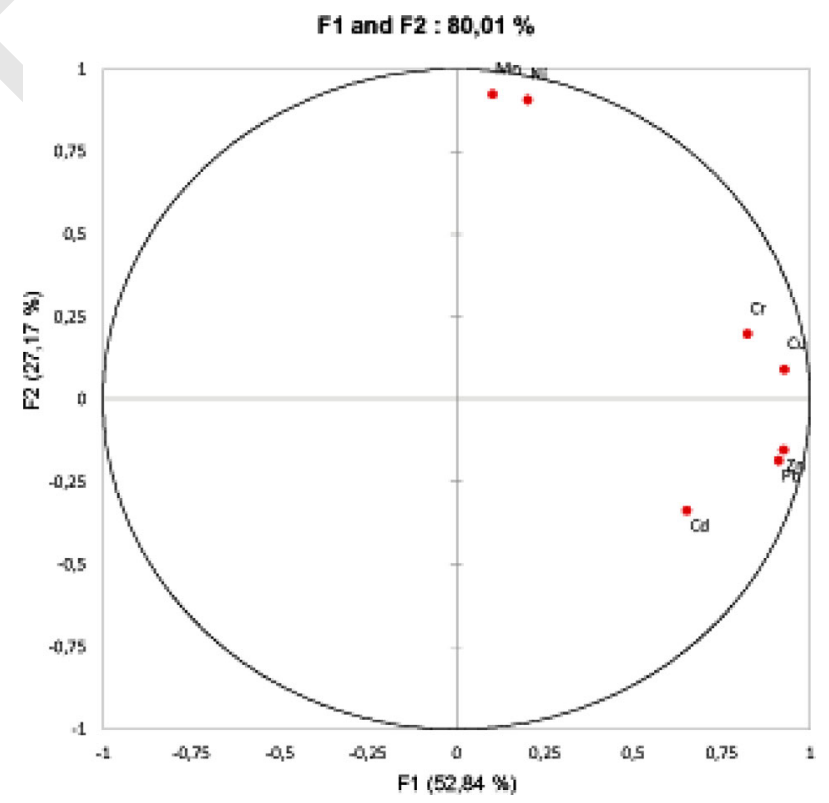

Figure 6. Loading of the parameters on the principal component axis.

- The second group (the GII group) is composed of the M5 station with $\mathrm{Cd}, \mathrm{Cu}, \mathrm{Pb}, \mathrm{Zn}$, and $\mathrm{Cr}$. This group presents the relation between the most contaminated station (M5) in the Meliane River and these elements $(\mathrm{Cd}, \mathrm{Cu}, \mathrm{Pb}, \mathrm{Zn})$. The source of 


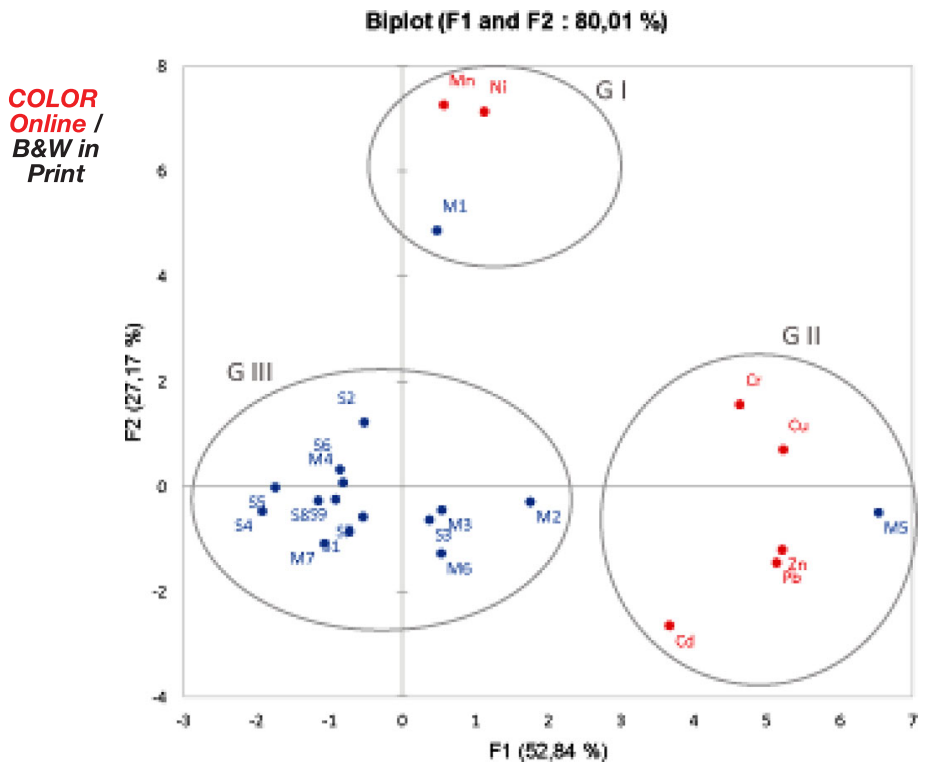

Figure 7. Loading of elements and stations on the principal component axis.

these metals is the domestic and industrial wastewater discharged into the Meliane River.

- The third group includes river stations that are not affected by the discharges into Meliane River and the marine stations of the Gulf of Tunis between Rades and Hammam-lif cities.

\section{Chemical speciation}

The use of sequential extraction techniques may provide very useful information regarding the chemical nature or potential mobility and bioavailability of a particular element, which can consequently offer a more realistic estimate of the actual environmental impact (Abdullah et al., 2019). Determining the total concentration of metals is arguably the most fundamental way to assess the quality of sediments; but for further understanding the potential mobility, bioavailability and toxicity of metals in sediments. The fractionation of metals makes it possible to assess the bioavailability and toxicity of metals.

The distribution of trace metals in different fractions of sediments is shown in Figure 4. Cd was present in the highest percentage in the exchangeable fraction, with an average of $57.22 \% . \mathrm{Zn}, \mathrm{Ni}$ and $\mathrm{Mn}$ were observed in the highest percentages in the reducible fraction, with average proportions of $50.54 \%$, $27.20 \%$ and $43.33 \%$, respectively. $\mathrm{Cu}$ and $\mathrm{Pb}$ dominated the oxidizable fraction, with average proportions of $47.77 \%$ and $47.84 \%$, respectively. Cr was present in the residual fraction with a percentage of $29.26 \%$.

\section{Cadmium}

The chemical speciation showed that $\mathrm{Cd}$ was mainly bound to the exchangeable fraction with percentages ranging from $54.11 \%$ to $84.92 \%$ in the Meliane River. However, in marine stations of the Gulf of Tunis between Rades and Hammam-lif cities, this percentage varied between $24.99 \%$ and $61.77 \%$. It explains the fact that the Meliane River could be the main source of $\mathrm{Cd}$. The high percentage of $\mathrm{Cd}$ bound to the exchangeable fraction lead to a potential environmental and ecological risks in the aquatic ecosystem.

The trace metals linked to the exchangeable fraction can easily migrate to the aqueous phase and have high bioavailability and toxicity (Li, 2007; Lin et al., 2014; Wang et al., 2015; Ben Amor et al., 2019). The average of abundance of $\mathrm{Cd}$ in the different fractions is as follows: exchangeable $>$ carbonatebound $>$ reducible $>$ oxidizable $>$ residual.

\section{Copper}

The chemical speciation performed on the surface sediments of the Meliane River shows that $\mathrm{Cu}$ is bound to the oxidizable fraction with percentage ranging from $27.01 \%$ to $95.01 \%$. The relative affinity of copper to the fraction bound to the oxidizable is due, in part, to the fact that copper compounds are stable (Stumm and Morgan, 1970; Smith and Martell, 1976; Rais, 1999). However, in the marine stations, chemical speciation shows that $\mathrm{Cu}$ is related to the residual fraction with percentages ranging from $8.43 \%$ to $72.57 \%$. The dominance of these two fractions (oxidable/residual) depends on many factors such as the organic matter content in the sediment and its degree of oxidation, the $\mathrm{Cu}$ anthropic contribution and the influence of the detritus (Rais, 1999). The average of the different fractions of $\mathrm{Cu}$ is in the order of: oxidizable $>$ residual $>$ exchangeable $>$ carbonatebound $>$ reducible.

\section{Lead}

The chemical speciation of $\mathrm{Pb}$ demonstrates the abundance of this metal in the oxidizable fraction with percentages ranging from $46.67 \%$ to $83.55 \%$, in the Meliane River, and from $2.02 \%$ to $50.75 \%$ in the marine stations. Lead is generally linked to organic matter and clay (Helali et al., 2016). The distribution of $\mathrm{Pb}$ to the oxidizable phase in the Meliane River increases slightly in the downstream. However, in the Gulf of Tunis between Rades and Hammam-lif cities, the percentage of the oxidizable raises from the north to the south. The oxidizable fraction is characterized by a low mobility and liberates a little quantity of trace 
Table 8. Individual (ICF), and global contamination factors (GCF) in the surface sediments of the Meliane River and marine stations of the Gulf of Tunis.

\begin{tabular}{lrrrrrrrr}
\hline & \multicolumn{7}{c}{ ICF } & \\
\cline { 2 - 7 } Stations & \multicolumn{1}{c}{$\mathrm{Cd}$} & \multicolumn{1}{c}{$\mathrm{Cu}$} & $\mathrm{Pb}$ & \multicolumn{1}{c}{$\mathrm{Zn}$} & \multicolumn{1}{c}{$\mathrm{Ni}$} & $\mathrm{Cr}$ & \multicolumn{1}{c}{$\mathrm{Mn}$} & \multicolumn{1}{c}{ GCF } \\
\hline M1 & 13.99 & 21.80 & 4.52 & 1.20 & 4.23 & 2.76 & 19.43 & 67.93 \\
M2 & 59.32 & 12.57 & 7.95 & 15.80 & 10.94 & 2.77 & 12.25 & 121.61 \\
M3 & 76.70 & 5.94 & 5.95 & 8.30 & 20.46 & 2.47 & 12.93 & 132.73 \\
M4 & 19.53 & 6.18 & 1.99 & 1.63 & 3.55 & 1.47 & 6.42 & 40.78 \\
M5 & 143.22 & 0.58 & 3.58 & 15.32 & 6.40 & 7.16 & 7.29 & 183.54 \\
M6 & 124.71 & 1.40 & 1.81 & 18.64 & 13.73 & 2.26 & 6.90 & 169.46 \\
M7 & 36.08 & 0.70 & 1.78 & 1.86 & 6.17 & 2.79 & 7.53 & 56.91 \\
S1 & 37.49 & 2.24 & 2.27 & 1.18 & 6.74 & 1.87 & 3.74 & 55.52 \\
S2 & 55.01 & 0.70 & 2.83 & 1.03 & 6.40 & 1.42 & 4.72 & 72.12 \\
S3 & 67.85 & 0.38 & 3.52 & 1.10 & 3.01 & 1.18 & 5.12 & 82.15 \\
S4 & 33.20 & 0.89 & 3.09 & 2.03 & 2.67 & 2.75 & 15.38 & 60.01 \\
S5 & 32.58 & 1.79 & 2.75 & 1.62 & 2.80 & 2.84 & 9.91 & 54.30 \\
S6 & 34.86 & 0.85 & 2.36 & 1.25 & 10.83 & 2.87 & 6.90 & 59.91 \\
S7 & 77.00 & 2.03 & 4.30 & 7.70 & 8.37 & 6.48 & 13.08 & 118.95 \\
S8 & 56.16 & 10.86 & 2.17 & 2.27 & 24.07 & 2.03 & 2.69 & 100.25 \\
S9 & 20.59 & 0.66 & 0.93 & 1.62 & 9.59 & 2.40 & 43.53 & 79.32 \\
\hline
\end{tabular}

metals into the environment (Filgueiras AV, 2002; Okbah et al., 2020). On the average, the abundance of $\mathrm{Pb}$ associated with different fractions was in the order of: oxidizable $>$ residual $>$ reducible $>$ exchangeable $>$ carbonate-bound.

\section{Zinc}

The chemical speciation performed on the surface sediments reveals that $\mathrm{Zn}$ is bound to the reducible fraction. The proportions of $\mathrm{Zn}$ in the reducible fraction range from $41.22 \%$ to $89 \%$, in the Meliane River, and from $36.14 \%$ to $72.92 \%$ in the Gulf of Tunis between Rades and Hammam lif cities. There is also a significant proportion related to the residual fraction with percentages ranging from $5.09 \%$ to $45.51 \%$, in the Meliane River, and from $11.49 \%$ to $49.36 \%$ in the marine stations. The average of the different fractions of $\mathrm{Zn}$ was in the order of: reducible $>$ residual $>$ carbonate-bound $>$ oxidizable $>$ exchangeable.

\section{Nickel}

The chemical speciation of $\mathrm{Ni}$ shows the abundance of this metal in the reducible fraction. It presents a percentage ranging from $17.6 \%$ to $30.55 \%$, in the Meliane River, and varies between $8.54 \%$ and $36.36 \%$ in the marine stations. The distribution of $\mathrm{Ni}$ in both river and marine stations demonstrates an approximate percentage of fractions linked to reducible, carbonate-bound and exchangeable fractions with an average of $27.2 \%, 22.17 \%$ and $20.34 \%$, respectively. The order of abundance of $\mathrm{Ni}$ is as follows: reducible $>$ carbonate-bound $>$ exchangeable $>$ oxidizable $>$ residual.

\section{Chromium}

The chemical speciation shows that $\mathrm{Cr}$ is bound to the residual fraction with percentages ranging from $12.26 \%$ to $40.41 \%$, in the Meliane River, and from $13.37 \%$ to $45.96 \%$ at the marine stations. In general, the residual fraction is a non-mobilizable phase. It is considered as geochemical background value of the elements in the sediment (Tessier et al., 1979; Li et al., 2020). The residual fraction is made essentially of detrital silicate minerals, refractory organic matter and resistant sulfides (Tessier et al., 1979). The order of the average of abundance of $\mathrm{Cr}$ in the different fractions is: residual $>$ exchangeable $>$ reducible $>$ carbonate-bound $>$ oxidizable.

\section{Manganese}

The chemical speciation demonstrates the abundance of $\mathrm{Mn}$ first to the reducible fraction in first degree and second to carbonate-bound. The percentages of the reducible fraction range between $33.72 \%$ to $50.28 \%$, in the Meliane River, and from $31.86 \%$ to $56.95 \%$ in the marine stations. For the carbonatebound, the percentages range from $26.33 \%$ to $50.23 \%$ and from $32.47 \%$ to $46.37 \%$ in the Meliane River and marine stations, respectively. The average of the different fractions of Mn was in the order of: reducible > carbonate-bound $>$ residual $>$ oxidizable $>$ exchangeable.

The chemical speciation used to know the proportions of trace metals in each fraction of surface sediments proves that $\mathrm{Cd}, \mathrm{Cu}, \mathrm{Pb}, \mathrm{Zn}, \mathrm{Ni}$ and $\mathrm{Mn}$ are associated to the non-residual fraction and only the $\mathrm{Cr}$ is bound to the residual fraction. The sources of trace metals in the surface sediments can be related to the anthropogenic origin from the industrial and domestic wastewater, which can be insufficiently treated, the surrounding farmland and the geological background. The anthropogenic contributions have exceeded natural inputs in the increases of trace metals accumulation in the environment, especially in developed areas with high population density and industrial activities (Wang et al., 2012; Hu et al., 2018; Huang et al., 2019).

\section{Pollution indicators}

The individual contamination factor (ICF) values show a high risk for $\mathrm{Cd}$ at all stations (Table 8). The ICF values of $\mathrm{Ni}$ and $\mathrm{Mn}$ are high in the Meliane River and in most marine stations. The $\mathrm{Cr}$ values were moderately affected by metallic trace elements $(1<\mathrm{ICF}<3)$ in most of the studied samples. The ICF values of $\mathrm{Pb}$ and $\mathrm{Zn}$ indicate moderate risks in 


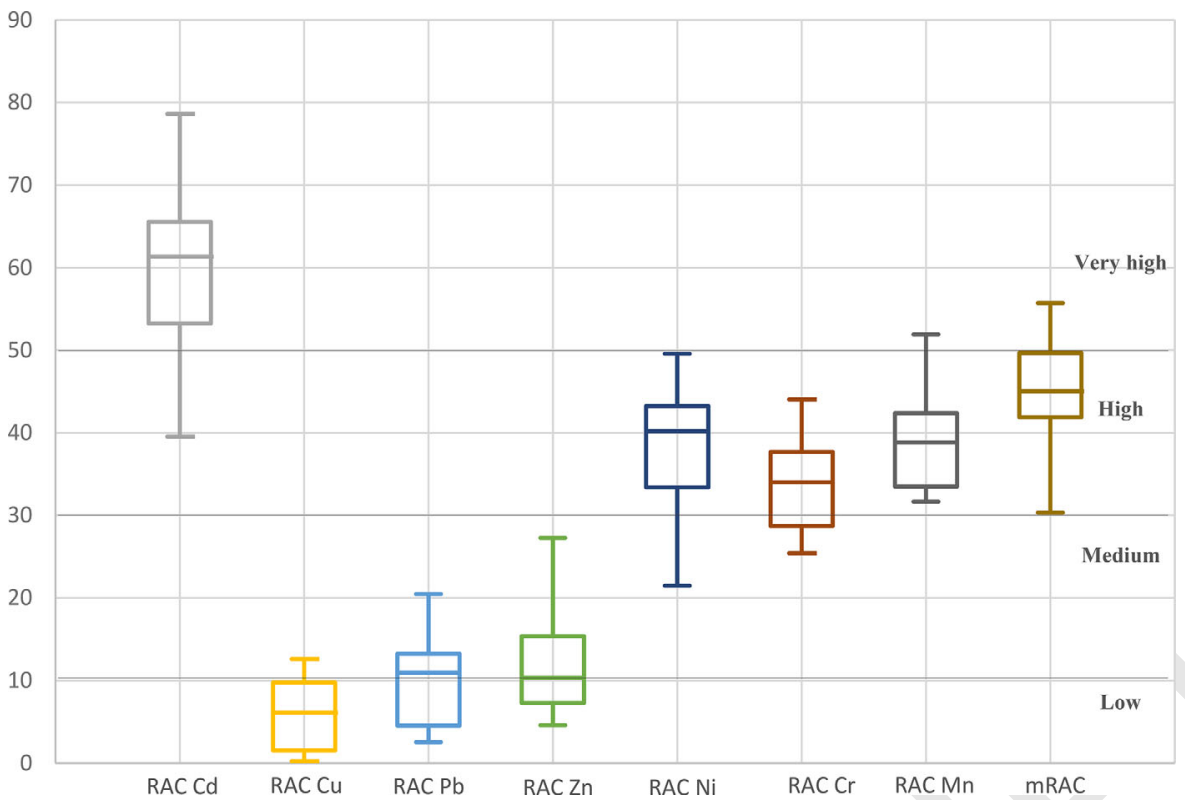

Figure 8. Box-plots of RAC and mRAC measured in the Meliane River and marine stations of the Gulf of Tunis.

the majority of stations; and oscillate from low to high contamination of $\mathrm{Cu}$. The global contamination factor (GCF) values expose a high risk for all samples (GCF > 24) from the Meliane River to the marine stations.

The box plot (Figure 8) of the risk assessment code (RAC) values demonstrates that the percentages of $\mathrm{Cu}, \mathrm{Pb}$ and $\mathrm{Zn}$ range from low risk to medium risk with percentages from 0.2 to $43 \%$, for $\mathrm{Cu}$, from 2.5 to $20.4 \%$, for $\mathrm{Pb}$, and from 4.6 to $27.3 \%$ for $\mathrm{Zn}$. The RAC values of $\mathrm{Ni}, \mathrm{Cr}$ and $\mathrm{Mn}$ show minimum percentages of $21.5 \%, 13.8 \%$ and $31.7 \%$, respectively, and maximum percentages of $49.6 \%, 51.4 \%$ and $51.9 \%$, respectively. The risk is therefore medium to high. The average percentage of Cadmium is $59.8 \%$. Thus, this element presents a very high environmental risk. The modified risk assessment code (mRAC) values range between $30.3 \%$ and $55.7 \%$ (Figure 8). They oscillate from a high to very high potential adverse effect. Discharges caused by coastal activities and urban wastes are adsorbed, to easily release the bound fractions, such as the exchangeable and carbonatebound fractions (Saeedi and Jamshidi-Zanjani, 2015; Soliman et al., 2018).

\section{Conclusion}

The distribution and the evaluation of metals in the surface sediments of the Meliane River and the marine stations of the Gulf of Tunis were assessed, in this work, using several tools and approaches (distribution of some trace metals $\mathrm{Cd}, \mathrm{Pb}, \mathrm{Zn}, \mathrm{Ni}, \mathrm{Cr}$ and $\mathrm{Cu}$, sequential extraction, numerous indices and statistical approaches). The study of the variation in the total concentrations of the surface sediments of $\mathrm{Cd}, \mathrm{Cu}, \mathrm{Pb}$, $\mathrm{Zn}, \mathrm{Ni}$ and $\mathrm{Cr}$ showed that the highest values were recorded in the downstream part of the Meliane River. The chemical speciation revealed that most of the $\mathrm{Cd}$ was bound to the exchangeable fraction, indicating its high bioavailability and toxicity. $\mathrm{Zn}, \mathrm{Ni}$ and Cr were mainly bound to the reducible fraction, while $\mathrm{Cu}$ and $\mathrm{Pb}$ were mostly associated with the oxidizable fraction, and $\mathrm{Cr}$ was related to the residual fraction. The distribution of the trace metals in the total concentrations of surface sediments was characterized by elements with high total contents values in the Meliane River. Obviously, it decreased in the marine stations. The high values of trace metals in River, which decrease in marine stations, resulted from the changes in the physicochemical parameters. This change started from the salt-freshwater mixed zone to the marine stations of the Gulf of Tunis. Pollution indicators and risk assessment indices were efficiently applied to evaluate the quality of surface sediments. The contamination and enrichment factors showed high values in the downstream part. The concentrations with trace metals in the surface sediments proved that the Meliane River is the main source of pollution in the Gulf of Tunis, essentially between the Rades and Hammam lif coast where the swimming is prohibited. The Meliane River drained different types of pollutants linked to the anthropogenic inputs. In addition to the different types of treated and untreated discharges, there is a solid waste discharge located in the river. Thus, we may conclude that the Meliane River is very susceptible and defenseless. There is a 
need to control the treatment of wastewater discharged in this river since contamination by discharges caused problems in the Gulf of Tunis between Rades and Hammam lif cities. Obviously, the Gulf of Tunis is a semi-enclosed area, which starts showing some signs of degradations.

\section{Acknowledgments}

The authors want to thank all members of the Department of Earth Sciences "Ardito Desio", of the University of Milan for their hospitality and their endorsement. The authors are also grateful to the laboratory team of the research unity of Geochemistry and Environmental Geology of the Faculty of Sciences of Tunis for their help and support. In addition, the authors would like also to thank the members of the Marine Environment laboratory of the Marine National Institute of Marine Sciences and Technologies for their help during sampling campaigns and the analyzing.

\section{References}

Abdallah, M. A. M., and Mohamed, A. A. 2019. Mobility and risk assessment of heavy metals by sequential extraction in coastal sediment south Mediterranean Sea, Egypt. Marine Systems \& Ocean Technology 14(1):42-50.

Added, A., Abdeljaoued, S., Essonni, N., and Fernex, F. 2003. Caractérisation géochimique des sédiments de surface du golfe de Tunis. Bulletin of the National Institute Sciences and Technologies Salammbô, Tunisia 30.

Agence nationale de Protection de l'Environnement (ANPE). 2014. Etude relative à l'actualisation de l'inventaire des principales sources potentielles de pollution des ressources hydriques (points chauds): gouvernorat Ben Arous.

Ahmad, M. K., Islam, S., Rahman, S., Haque, M., and Islam, M. M. 2010. Heavy metals in water, sediment and some fishes of Buriganga River, Bangladesh. International Journal of Environmental Research 4:321-332.

Ahmedat, C., Dabi, S., Zahraoui, M., and El Hassani, I. E. E. A. 2018. Spatial distribution of stream sediment pollution by toxic trace elements at Tourtit and Ichoumellal abandoned mining areas (central Morocco). Arabian Journal of Geosciences 11(3):5.

Almeida, J. A., Diniz, Y. S., Marques, S. F. G., Faine, L. A., Ribas, B. O., Burneiko, R. C., et al. 2002. The use of the oxidative stress responses as biomarkers in Nile tilapia (Oreochromis niloticus) exposed to in vivo cadmium contamination. Environment International 27(8):673-679.

Ayadi, M., and Bargaoui, Z. 1998. Modélisation des écoulements de l'oued Miliane par le modèle CEQUEAU. Hydrological Sciences Journal 43(5):741-758.

Ayari, R., and Afli, A. 2008. Functional groups to establish the ecological quality of soft benthic fauna within Tunis Bay (Western Mediterranean). Vie et Milieu-Life and Environnement 58(1):67-75.

Ben Amor, R., Yahyaoui, A., Abidi, M., Chouba, L., and Gueddari, M. 2019. Bioavailability and assessment of metal contamination in surface sediments of rades- hamam lif coast, around Meliane River (Gulf of Tunis, Tunisia, Mediterranean Sea). Journal of Chemistry 2019.

Ben Ayed, N., Bodou, P., Jarrige, J. J., and Viguier, C. 1984. Géodynamique de quelques bassins sédimentaires Tunisiens: Tectonique synsédimentaire oligocène autour du golfe de Tunis. 10ème réunion annuelle des Sciences de la terre, Bordeaux. Paris: Societe Geologique de France, $44 \mathrm{p}$.

Ben Charrada, R. 1997. Etude hydrodynamique et écologique du complexe petit golfe-lac de Tunis. Contribution à la modélisation de l'écosystème pélagique des eaux côtièrespetit golfe de Tunis. Diplôme de doctorat génie hydraulique.

Ben Lamine, Y., Daly Yahia-Kefi, O., and Daly Yahia, N. 2012. Planktonic copepod community in the Neritic area of the south western part of Tunis bay influenced by Meliane river supplies (south western Mediterranean Sea). Bulletin de Institut National des Science et Technologies de Mer de Salammbô 39.

Bhuyan, M. S., Bakar, M. A., Rashed-Un-Nabi, M., Senapathi, V., Chung, S. Y., and Islam, M. S. 2019. Monitoring and assessment of heavy metal contamination in surface water and sediment of the Old Brahmaputra River, Bangladesh. Applied Water Science 9(5):125.

Brady, J. P., Ayoko, G. A., Martens, W. N., and Goonetilleke, A. 2015. Development of a hybrid pollution index for heavy metals in marine and estuarine sediments. Environmental Monitoring and Assessment 187(5): 306

Brahim, M., Abdelfattah, A., Sammari, C., and Aleya, L. 2015. Surface sediment dynamics along with hydrodynamics along the shores of Tunis Gulf (north-eastern Mediterranean). Journal of African Earth Sciences 103: $30-41$.

Caglar, M., Canpolat, O., and Selamoglu, Z. 2019. Determination of some heavy metal levels in three freshwater fish in Keban Dam Lake (Turkey) for public consumption. Iranian Journal of Fisheries Sciences 18(1): 188-198.

Chen, C. F., Dong, C. D., and Chen, C. W. 2013. Metal speciation and contamination in dredged harbor sediments from Kaohsiung Harbor, Taiwan. Soil and Sediment Contamination: An International Journal 22(5):546-561.

Chetty, S., and Pillay, L. 2019. Assessing the influence of human activities on river health: A case for two South African rivers with differing pollutant sources. Environmental Monitoring and Assessment 191(3):168.

Cukrov, N., Frančišković-Bilinski, S., Hlača, B., and Barišić, D. 2011. A recent history of metal accumulation in the sediments of Rijeka harbor, Adriatic Sea, Croatia. Marine Pollution Bulletin 62(1):154-167.

Dawson, E. J., and Macklin, M. G. 1998. Speciation of heavy metals in floodplain and flood sediments: a reconnaissance survey of the Aire Valley, West Yorkshire, Great Britain. Environmental Geochemistry and Health 20(2): 67-76.

Demirak, A., Yilmaz, F., Tuna, A. L., and Ozdemir, N. 2006. Heavy metals in water, sediment and tissues of Leuciscus cephalus from a stream in southwestern Turkey. Chemosphere 63(9):1451-1458.

Dou, Y., Li, J., Zhao, J., Hu, B., and Yang, S. 2013. Distribution, enrichment and source of heavy metals in 
surface sediments of the eastern Beibu Bay, South China Sea. Marine Pollution Bulletin 67(1-2):137-145.

El Arrim, A. 1996. Etude d'impact de la dynamique sédimentaire et des aménagements sur la stabilité du littoral du golfe de Tunis. PhD thesis, Faculty of Sciences of Tunis, University of Tunis El Manar, Tunis.

Ennouri, R., Chouba, L., Magni, P., and Kraiem, M. M. 2010. Spatial distribution of trace metals $(\mathrm{Cd}, \mathrm{Pb}, \mathrm{Hg}$, $\mathrm{Cu}, \mathrm{Zn}, \mathrm{Fe}$ and $\mathrm{Mn}$ ) and oligo-elements $(\mathrm{Mg}, \mathrm{Ca}, \mathrm{Na}$ and $\mathrm{K})$ in surface sediments of the Gulf of Tunis (Northern Tunisia). Environmental Monitoring and Assessment 163(1-4):229-239.

Filgueiras, A. V., Lavilla, I., and Bendicho, C. 2002. Chemical sequential extraction for metal partitioning in environmental solid samples. Journal of Environmental Monitoring: JEM 4(6):823-857.

Gargouri, D., Gzam, M., Kharroubi, A., and Jedoui, Y. 2018. Use of sediment quality indicators for heavy metals contamination and ecological risk assessment in urbanized coastal zones. Environmental Earth Sciences 77(10): 381.

Ghrefat, H., and Yusuf, N. 2006. Assessing Mn, Fe, Cu, Zn, and $\mathrm{Cd}$ pollution in bottom sediments of Wadi Al-Arab Dam, Jordan. Chemosphere 65(11):2114-2121.

Hakanson, L. 1980. An ecological risk index for aquatic pollution control. A sedimentological approach. Water Research 14(8):975-1001.

Helali, M. A., Oueslati, W., Zaaboub, N., Added, A., and Aleya, L. 2016. Chemical speciation of $\mathrm{Fe}, \mathrm{Mn}, \mathrm{Pb}, \mathrm{Zn}$, $\mathrm{cd}, \mathrm{cu}, \mathrm{co}, \mathrm{Ni}$ and $\mathrm{Cr}$ in the suspended particulate matter off the Mejerda River Delta (gulf of Tunis, Tunisia). Journal of African Earth Sciences 118:35-44.

Hilton, J., Davison, W., and Ochsenbein, U. 1985. A mathematical model for analysis of sediment core data: Implications for enrichment factor calculations and tracemetal transport mechanisms. Chemical Geology 48(1-4): 281-291.

Hu, B., Zhao, R., Chen, S., Zhou, Y., Jin, B., Li, Y., et al. 2018. Heavy metal pollution delineation based on uncertainty in a coastal industrial city in the Yangtze River Delta, China. International Journal of Environmental Research and Public Health 15(4):710.

Huang, S., Shao, G., Wang, L., Wang, L., and Tang, L. 2019. Distribution and health risk assessment of trace metals in soils in the golden triangle of Southern Fujian province, China. International Journal of Environmental Research and Public Health 16(1):97.

Ikem, A., Egiebor, N. O., and Nyavor, K. 2003. Trace elements in water, fish and sediment from Tuskegee Lake, Southeastern USA. Water, Air, and Soil Pollution 149(1-4):51-75.

Ip, C. C., Li, X. D., Zhang, G., Wai, O. W., and Li, Y. S. 2007. Trace metal distribution in sediments of the Pearl River Estuary and the surrounding coastal area, South China. Environmental Pollution (Barking, Essex: 1987) 147(2):311-323.

Jain, C. K. 2004. Metal fractionation study on bed sediments of River Yamuna, India. Water Research 38(3):569-578.

Jones, I., Kille, P., and Sweeney, G. 2001. Cadmium delays growth hormone expression during rainbow trout development. Journal of Fish Biology 59(4):1015-1022.
Jouirou, M. 1982. Faciès sédimentaires et processus dynamiques dans la formation d'un milieu lagunaire: évolution Holocène et actuelle du lac de Tunis et de ses abords. Thèse 3ème cycle, Bordeaux I, 1218-1746.

Joy, A., Anoop, P. P., Rajesh, R., Mathew, A., and Gopinath, A. 2019. Spatial distribution and contamination assessment of trace metals in the coral reef sediments of Kavaratti Island in Lakshadweep Archipelago, Indian Ocean. Soil and Sediment Contamination: An International Journal 1-23.

Khabouchi, I., Khadhar, S., Driouich Chaouachi, R., Chekirbene, A., Asia, L., and Doumenq, P. 2020. Study of organic pollution in superficial sediments of Meliane river catchment area: aliphatic and polycyclic aromatic hydrocarbons. Environmental Monitoring and Assessment 192:1-9.

Khadhar, S., Achour, D., Chekirben, A., Chawachi, R., Mlayah, A., and Charef, A. 2018. Sediment-water column exchange of persistent organic pollutants (PAH s and PCB s) and their transport vector in El Bey Watershed, Tunisia. Arabian Journal of Geosciences 11(17):522.

Köse, E., Emiroğlu, Ö., Çiçek, A., Aksu, S., Başkurt, S., Tokatli, C., et al. 2019. Assessment of ecologic quality in terms of heavy metal concentrations in sediment and fish on Sakarya River and Dam Lakes, Turkey. Soil and Sediment Contamination: An International Journal 1-12.

Leung, H. M., Duzgoren-Aydin, N. S., Au, C. K., Krupanidhi, S., Fung, K. Y., Cheung, K. C., et al. 2017. Monitoring and assessment of heavy metal contamination in a constructed wetland in Shaoguan (Guangdong Province, China): bioaccumulation of $\mathrm{Pb}, \mathrm{Zn}, \mathrm{Cu}$ and $\mathrm{Cd}$ in aquatic and terrestrial components. Environmental Science and Pollution Research 24(10):9079-9088.

Li, G. 2007. Environmental Geochemistry of Heavy Metals and Depositional Environment in Xiamen seas Qingdao. Qingdao, China: Ocean University of China.

Li, X., Lee, S. L., Wong, S. C., Shi, W., and Thornton, I. 2004. The study of metal contamination in urban soils of Hong Kong using a GIS-based approach. Environmental Pollution (Barking, Essex: 1987) 129(1):113-124.

Li, X., Shen, Z., Wai, O. W., and Li, Y. S. 2020. Chemical partitioning of heavy metal contaminants in sediments of the Pearl River Estuary. Chemical Speciation \& Bioavailability 12(1):17-25.

Lin, C., Liu, Y., Li, W., Sun, X., and Ji, W. 2014. Speciation, distribution, and potential ecological risk assessment of heavy metals in Xiamen Bay surface sediment. Acta Oceanologica Sinica 33(4):13-21.

Liu, S., Wang, Z., Zhang, Y., Liu, Y., Yuan, W., Zhang, T., et al. 2019. Distribution and partitioning of heavy metals in large anthropogenically impacted river, the Pearl River, China. Acta Geochimica 38(2):216-231.

Lusher, J. A., and Ramsden, H. T. 2000. Water pollution. In Environmental Management in South Africa. 3rd. ed. Cape Town, South Africa: Juta and Company, Limited, 456-492.

McGeer, J. C., Szebedinszky, C., McDonald, D. G., and Wood, C. M. 2000. Effects of chronic sublethal exposure to waterborne $\mathrm{Cu}, \mathrm{Cd}$ or $\mathrm{Zn}$ in rainbow trout. 1: Ionoregulatory disturbance and metabolic costs. Aquatic Toxicology (Amsterdam, Netherlands) 50(3):231-243. 
Okbah, M. A., El-Gammal, M. I., Ibrahim, M. S., and Waheshi, Y. A. 2020. Geochemical speciation of trace metals in sediments of the northern Nile Delta Lake by sequential extraction technique. Chemistry and Ecology 36(3):236-255.

National Office of Assessment (ONAS). 2008. Etude de recherche des sources de pollution au niveau de l'Oued Meliane et l'Oued Khelij et propositions de solutions d'élimination. National Report. Tunisian Republic: National Office of Sanitation, Ministry of Local Affairs and the Environment.

Pekey, H. 2006. The distribution and sources of heavy metals in Izmit Bay surface sediments affected by a polluted stream. Marine Pollution Bulletin 52(10):1197-1208.

Perin, G., Craboledda, L., Lucchese, M., Cirillo, R., Dotta, L., Zanette, M. L., et al. 1985. Heavy metal speciation in the sediments of northern Adriatic Sea. A new approach for environmental toxicity determination. Heavy Metals in the Environment 2(1):454-456.

Raghunath, R., Tripathi, R. M., Kumar, A. V., Sathe, A. P., Khandekar, R. N., and Nambi, K. S. V. 1999. Assessment of $\mathrm{Pb}, \mathrm{Cd}, \mathrm{Cu}$, and $\mathrm{Zn}$ exposures of 6- to 10-year-old children in Mumbai. Environmental Research 80(3): 215-221.

Rais, M. 1999. Géochimie des métaux lourds ( $\mathrm{Fe}, \mathrm{Mn}, \mathrm{Pb}$, $\mathrm{Zn}, \mathrm{Cu}$, Ni et $\mathrm{Cd}$ ) dans les eaux et les sédiments du littoral du golfe de Tunis. Mobilité et impact des activités anthropiques. PhD thesis, Faculty of Sciences of Tunis, University of Tunis El Manar, Tunis.

Saeedi, M., and Jamshidi-Zanjani, A. 2015. Development of a new aggregative index to assess potential effect of metals pollution in aquatic sediments. Ecological Indicators 58:235-243.

Saïdi, H., Souissi, R., and Zargouni, F. 2013. Environmental impacts of single and successive breakwaters along the Mediterranean coastline at Radès-Ezzahra, NE Tunisia. Bulletin of Engineering Geology and the Environment 72(1):81-91.

Sakan, S. M., Sakan, N. M., and Đorđević, D. S. 2013. Trace element study in $\sim$ Tisa River and Danube alluvial sediment in Serbia. International Journal of Sediment Research 28(2):234-245.

Sliti, M. 1990. Fonctionnement des brise-lames dans le système littoral du golfe de Tunis. Thèse de 3ème cycle, Université de Bordeaux I, $204 \mathrm{p}$.

Smith, R. M., and Martell, A. E. 1976. Critical Stability Constants: Inorganic Complexes, Vol. 4. New York: Plenum Press, 96-103.

Soliman, N. F., Nasr, S. M., and Okbah, M. A. 2015. Potential ecological risk of heavy metals in sediments from the Mediterranean coast, Egypt. Journal of Environmental Health Science \& Engineering 13(1):70.

Soliman, N. F., Younis, A. M., Elkady, E. M., and Mohamedein, L. I. 2018. Geochemical associations, risk assessment, and source identification of selected metals in sediments from the Suez Gulf, Egypt. Human and Ecological Risk Assessment: An International Journal 25(3):738-754.
Souissi, S., Yahia-Kéfi, O. D., and Yahia, M. D. 2000. Spatial characterization of nutrient dynamics in the Bay of Tunis (south-western Mediterranean) using multivariate analyses: consequences for phyto-and zooplankton distribution. Journal of Plankton Research 22(11): 2039-2059.

Stumm, W., and Morgan, J. J. 1970. Aquatic Chemistry; an Introduction Emphasizing Chemical Equilibria in Natural Waters.

Sutherland, R. A. 2000. Bed sediment-associated trace metals in an urban stream, Oahu, Hawaii. Environmental Geology 39(6):611-627.

Tessier, A., Campbell, P. G., and Bisson, M. 1979. Sequential extraction procedure for the speciation of particulate trace metals. Analytical Chemistry 51(7):844-851.

Tzimopoulos, C., Zeibeki, A., Ginidi, P., and Evangelides, C. 2005. Water resources management in the watershed of Volvi lake. Global NEST Journal 7(3):379-385.

Wang, M., Markert, B., Chen, W., Peng, C., and Ouyang, Z. 2012. Identification of heavy metal pollutants using multivariate analysis and effects of land uses on their accumulation in urban soils in Beijing, China. Environmental Monitoring and Assessment 184(10): 5889-5897.

Wang, Z., Wang, Y., Chen, L., Yan, C., Yan, Y., and Chi, Q. 2015. Assessment of metal contamination in coastal sediments of the Maluan Bay (China) using geochemical indices and multivariate statistical approaches. Marine Pollution Bulletin 99(1-2):43-53.

Xu, Y. J., Liu, X. Z., and Ma, A. J. 2004. Current research on toxicity effect and molecular mechanism of heavy metals on fish. Marine sciences-Qingdao-Chinese Edition 28(10):67-70.

Yahia, M. N. D., Souissi, S., and Yahia-Kéfi, O. D. 2004. Spatial and temporal structure of planktonic copepods in the Bay of Tunis (southwestern Mediterranean Sea). Zoological Studies 43(2):366-375.

Yi, Y., Yang, Z., and Zhang, S. 2011. Ecological risk assessment of heavy metals in sediment and human health risk assessment of heavy metals in fishes in the middle and lower reaches of the Yangtze River basin. Environmental Pollution (Barking, Essex: 1987) 159(10):2575-2585.

Zaaboub, N., Oueslati, W., Amine Helali, M., Abdeljaouad, S., Javier Huertas, F., and Lopez Galindo, A. 2014b. Trace elements in different marine sediment fractions of the Gulf of Tunis (Central Mediterranean Sea). Chemical Speciation \& Bioavailability 26(1):1-12.

Zaaboub, N., Ounis, A., Helali, M. A., Béjaoui, B., Lillebø, A. I., da Silva, E. F., et al. 2014a. Phosphorus speciation in sediments and assessment of nutrient exchange at the water-sediment interface in a Mediterranean lagoon: implications for management and restoration. Ecological Engineering 73:115-125.

Zhang, Z., Juying, L., Mamat, Z., and QingFu, Y. 2016. Sources identification and pollution evaluation of heavy metals in the surface sediments of Bortala River, Northwest China. Ecotoxicology and Environmental Safety 126:94-101. 